\title{
The Application Of Justice Principles Of Rapid Simple Fee In Criminal Justice System In The State Court (Case Study in State court of Pati)
}

\author{
Lailatul Nur Hasanah $^{1}$ and Sri Endah Wahyuningish ${ }^{2}$
}

Abstract. This study aims to determine and analyze the application of the principle of simple justice Rapid Simple Fee in the criminal justice system in the State court of Pati. As well as to identify and explain the barriers and solutions simple application of the principle of justice Rapid Simple Fee in the judicial system in State court of Pati. And to identify and explain the contribution principle is simple justice Rapid Simple Fee in the criminal justice system to reform the criminal justice system in the future.

This study uses empirical juridical approach to analysis of the application of the principle of judicial issues simple, quick and inexpensive in the criminal justice system in the State court of Pati. Specifications research is descriptive analysis. With data collection techniques are primary and secondary data and research literature, analyzed using qualitative. The problem is analyzed with the theory of law enforcement and progressive legal theory. The results of this study showed that every judge shall comply with the laws that have been set ie power Act No. 48 of 2009 and Act No. 8 of 1981. Constraints in principle to simple justice Rapid Simple Fee is the human resources of the apparatus law enforcement, lack law enforcement and courtroom facilities, absence of the parties or witnesses. The solution is to determine the court calendar, giving sanction to the litigants or witnesses who have been called State court of Pati. Contributions in future expected law enforcement qualified for handling the case, mutual cooperation between law enforcement agencies and is able to imitate the criminal justice system in developed countries such as settling disputes out of court with mediation mechanism penal (penal mediation), restorative justice, diversion in juvenile justice and other forms that thrive in the community. It is considered necessary as part of the criminal law reform. Contributions in future expected law enforcement qualified for handling the case, mutual cooperation between law enforcement agencies and is able to imitate the criminal justice system in developed countries such as settling disputes out of court with mediation mechanism penal (penal mediation), restorative justice, diversion in juvenile justice and other forms that thrive in the community. It is considered necessary as part of the criminal law reform. Contributions in future expected law enforcement qualified for handling the case, mutual cooperation between law enforcement agencies and is able to imitate the criminal justice system in developed countries such as settling disputes out of court with mediation mechanism penal (penal mediation), restorative justice, diversion in juvenile justice and other forms that thrive in the community. It is considered necessary as part of the criminal law reform.

Keywords: Principle of Simple Justice, Rapid Simple Fee In Criminal Justice System in Pati Court

\footnotetext{
${ }^{1}$ Student of Master of Law, Universitas Islam Sultan Agung Semarang and Lawyer Staff, email lailanurhasna@gmail.com

${ }^{2}$ Lecturer of Master of Law, Sultan Agung Islamic University (UNISSULA), Semarang
} 


\section{Introduction}

The Constitution of the Republic of Indonesia 1945 Article 1 (3) is a state based on law. Indonesia as a country upholding the law and human dignity in conjunction with the law and the government must uphold the law with no exception. In the principle of Pancasila to -5 reads "Social justice for all Indonesian people" can be explained that in such a case, one of which relates to the law the people of Indonesia are entitled to justice in truth $^{3}$

Principles contained in the Justice Courts Simple, Rapid Simple Fee set out in Article 2 (4) of Act No. 48 Of 2009 on Judicial Power. ${ }^{4}$ In Act No. 1981 on Criminal Proceedings not be explained in general about the principle is simple, fast and inexpensive, but the principle should be mandated, that the principles governing the protection of human dignity which was laid in the Act No. 482009 on judicial Power must be upheld in Act No. 8 of 1981 on Criminal Proceedings, among other judicial principle is simple, quick and low cost as well as honest and impartial smoking should be applied in layers of courts $^{5}$,

Understanding simple and inexpensive in the Law on Judicial Power Number 48 Of 2009 regarding the intention of the Simple is the examination and settlement is done with an effective and efficient manner. While fast can be measured in the ordinary perceived by the public in basic treatment professionals from law enforcement officers to a case such as the Police immediately conduct investigations and delegate, and prosecutors immediately assign and demanding while the Judge immediately hear and decide based without delay and with a sense of responsibility responsible by the judge. $^{6}$

Legislation mean by low cost is the cost of the case can be reached by the public ${ }^{7}$ If a delay of settlement of criminal incident was deliberate, of course is the rape of the law and human dignity. ${ }^{8}$

Misery suspect who tossed around by a sense of legal uncertainty of protracted caused suspicion or indictment that accused him of haunting him without a final resolution. In the trial schedule often in retreat with all kinds of reasons that are not basic as pain or member judges His clerk yet to come, the meeting room does not exist or is full, or perhaps his company was being lazy and let the defendant sat waiting like worthless trash. Then the clock struck one in the afternoon, the accused is called to notify the case investigation was delayed because the office hours are up. Defendant forced return breathed in crying over the body of fortune is always haunted by worries and anxiety. ${ }^{9}$ Criminal Procedure Code has laid a foundation as a principle or principles of justice should be done with a simple, fast and inexpensive. In principle the application of the principle of judicial simple, quick and low cost will make a reality in law enforcement in Indonesia if realized with moral, application of the principle has not

\footnotetext{
${ }^{3}$ Act 1945

${ }^{4}$ Act No. 48 of 2009

${ }^{5}$ Act No. 8 of 1981

${ }^{6}$ Ibid, p.285

${ }^{7}$ Elucidation of Article 2 (4) of Act No. 48 of 2009.p.52

${ }^{8}$ Ibid, p.53

${ }^{9}$ M. Yahya Harahap, 2017, Pembahasan Permasalahan dan Penerapan KUHAP, Jakarta: Sinar Grafika, p.52
} 
been guaranteed, law enforcement decisive as to support the ideals of law enforcement a powerful understand them not as mere instruments of power but human group or waitress (agency of service) consciousness that gives motivation to carry out the spirit of legal services that are simple, fast and inexpensive. ${ }^{10}$

Based on the facts and events of their things as above and the Regulation of the Criminal Procedure Code and Act No. 48 Of 2009 regarding Judicial then Authors interested in taking research with title "Application of Principle of Justice is simple, Rapid Simple Fee In The Criminal Justice System in the State court of Pati ( Case Study in State court of Pati)."

Based on the background of the problems above, the present study found the formulation of the problem, namely: How simple application of the principle of justice Rapid Simple Fee in the criminal justice system in the State court of Pati?; How the application of the principle obstacles and solutions Rapid Simple Fee in the criminal justice system in the State court of Pati; How to contribute judicial application of the principle is Rapid Simple Fee in the criminal justice system in State court of Pati for the renewal of the criminal justice system in the future?

\section{Research methods}

The method used in this research is empirical juridical approach. Is reviewing the concept of normative juridical or legislation while empirically examine the realities of the Application of Principle of Rapid Simple Fee In Justice System in State court of Pati. Methods of data collection consist of primary data and secondary data. Primary data include interviews sampling technique used in this research is purposive non-random sampling, which in determining the sample with a certain consideration which is deemed to provide random data is taking people who elected completely by the researchers according to the characteristics that owned by the sample.

Methods of Data Analysis Data analysis in this research used descriptive qualitative method. ${ }^{11}$ Qualitative Methods is a research procedure that produces descriptive data in the form of written words of people and behaviors that can be observed. ${ }^{12}$

\section{Results And Discussion}

\subsection{Simple Application Of The Principle Of Justice Rapid Simple Fee In The Criminal Justice System In The State Court Of Pati}

Since the enactment of the Criminal Procedure Code in 1981 is a matter of transparency, professionalism and integrity of law enforcement, including certain legal adviser causing victims justice seekers who are often constrained to obtain legal certainty since the arrest or detention, and even to the court ${ }^{13}$,

\footnotetext{
${ }^{10}$ M. Yahya Harahap, Ibid, p. 53

${ }^{11}$ Nurhan Bungi, 2003, Analisis Data dan Penelitian Kulaitatif, Pemahamn filosofis dan Metodologis kearah penguasaan Modal Aplikasi, Jakarta: Raja Grafindo Persada, p. 53

${ }^{12}$ Ibid, p. 104

${ }^{13}$ Act Criminal Procedure Law, Opcit.p.52
} 
But for the problems of the subject is the principle of justice is simple, fast and low cost in the criminal justice system in the State court of Pati. State court of Pati examine and decide the cases that come out of the criminal justice system through the police investigation of the prosecutor's office so that the State court of Pati not carelessly give judgment or trial for the sake of realizing the principle of justice is simple, fast and inexpensive, and the judge must explore, understand legal values and sense of justice who live in the community. ${ }^{14}$

Strategies undertaken by the State court Starch is

- Simplify litigation

In this case the rapid completion performed on the day, date, time, and place specified in accordance with the court specified calendar. Then the cases judged by a quick check at the same event published in the book register with each given a number to be completed sequentially.

The proceedings (court calendar) Case Number: 162 / Pid.Sus / PN.Pati defendant on Rahmat Imron Prasetyo Bin Jalil violating Article 310 paragraph (2) Act No. 22 of 2009 on traffic and road transport.

Table 1

Trial schedule (court calendar) State court of Pati Case Number: 162 / Pid.Sus / PN.Pati ${ }^{15}$

\begin{tabular}{|c|l|l|l|l|}
\hline No. & Court Hearing & Day & date & Information \\
\hline 1. & reading of the indictment & Wednesday & $30-10-2019$ & \\
\hline 2. & $\begin{array}{l}\text { exception: } \\
\text { Public opinion } \\
\text { Responses Defendant / PH }\end{array}$ & & \\
\hline 3. & Injunctions & & & \\
\hline 4. & $\begin{array}{l}\text { Examination of Evidence } \\
\text { a. chance I } \\
\text { b. opportunity II } \\
\text { c. opportunity III }\end{array}$ & & & \\
\hline 5. & $\begin{array}{l}\text { The examination of witnesses } \\
\text { Ade Charge } \\
\text { a. chance I } \\
\text { b. opportunity II }\end{array}$ & & & \\
\hline 6. & examination of the Defendant & Wednesday & $20-11-2019$ & \\
\hline 7. & $\begin{array}{l}\text { Demand } \\
\text { a. chance I } \\
\text { b. opportunity II }\end{array}$ & Wednesday & $06-11-2019$ & \\
\hline 8. & Defense & & & \\
\hline 9. & Reply & Wednesday & $13-11-2019$ & \\
\hline 10 & Rejoinder & & & \\
\hline 11 & Decision & Wednesday & $20-11-2019$ & \\
\hline
\end{tabular}

${ }^{14}$ Informant Interview Judge A.A Putu Putra Ariyana (December 9, 2019. 09.00 pm. In the State Court of Pati)

${ }^{15}$ Source: State Court of Pati, 2019 
These provisions provide certainty in the judge by a quick examination shows it is not necessary that the indictment prepared by the prosecutor as to the examination with regular events, but the offenses charged sufficiently written in the register book, to accelerate the settlement is done with full accuracy. Event justice quickly examine and decide with a single judge and deciding cases are more complex then can be checked by the judges.

In the criminal justice system in the State court Case Number Pati check 162 / Pid Sus./2019/PN.Pati on behalf of the defendant Rahmat Imron Prasetyo Bin Jalil without counsel State court of Pati defendant proven legally and convincingly guilty of committing a criminal offense to drive a motor vehicle that because of the result in a traffic accident with minor injuries and damage to vehicles as article 310 paragraph (2) Act No. 22 of 2009 on traffic and road transport. By imprisonment for one (1) months and five (5) days and a fine Rp.1000.000 (one million rupiah) if the fine was not paid to be replaced by imprisonment for 1 (one) month and establishes that the defendant pay the court fee of Rp. 2500., (Two thousand five hundred thousand rupiah) In such case the defendant detained by a warrant or detention establishment prosecutor from the date of October 21, 2019 until November 9, 2019 and State court Judge Starch from the date of October 23, 2019 until 21 November 2019. According to Judge case Number: 162 / Pid Sus / 2019 / PN.Pti State court of Pati had sought to apply the principles of judicial quick simple and inexpensive even in the examination proceedings must sometimes be delayed as it waits for the litigant parties. And containment could be reduced if there is professionalism and cooperation among law enforcement officers handling the case.

- Improving case management

- Establish a working mechanism that is capable of functioning as a control tool towards settlement

- Implementation of a perfect legal framework

Based on the interview Judge A.A Putu Putra Ariyana say in the running of the criminal justice system is based on the principle of simple justice Rapid Simple Fee in State court of Pati is in accordance with the Theory of Law Enforcement and Legal Theory Progressive although in practice less than the maximum and still many obstacles. As a judge in tackling the crime problem we are guided by the Criminal Code (law criminal law), Act No. 48 of 2009 on the judicial authorities in accordance with Article 2 (4) and run the justice system in accordance Criminal Procedure Code (the book of the law of criminal procedural law ). Related mild case should not be on trial as the judge expects it to be not much case filed in court by the Criminal Code provisions could be improved and clarified. ${ }^{16}$

\subsection{Obstacles And Solutions Simple Application Of The Principle Of Justice Rapid Simple Fee In The Criminal Justice System In The State Court Of Pati}

\footnotetext{
${ }^{16}$ Interview informant A.A Putu Putra Ariyana, SH (December 9th, 2019, at 09:00 am at the State Court of Pati).
} 
Barriers experienced by law enforcement officials in the application of the principle of judicial quick simple and low cost in the criminal justice system in State court of Pati are as follows:

- Internal barriers

The resistance of the existing system that is ${ }^{17}$ :

- Limited human resources on the part of law enforcement officials both from investigators, prosecutors, judges and lawyers, in a settlement to the case. As more cases than implementing both personal and facilities

- An understanding of the principles of simple justice Rapid Simple Fee that has not fully entered into the thoughts of each law enforcement (the old mindset oriented legal process remain to be implemented.

- External barriers

- The absence of the parties litigant defendant or witnesses in the trial in the State court of Pati

- Incomplete case file so it can not be heard so that the judge returns the case file to the prosecutor's office and finally adjourned

- The lack of legal awareness to the community in realizing the principle of simple justice fast and inexpensive so become an obstacle to the trial process in the trial schedule has been determined for example, but the parties were late ${ }^{18}$

- Solutions To Apply The Principle Of Simple Justice Rapid Simple Fee Of The Criminal Justice System In The State Court Of Pati

Based on the obstacles or barriers in the face by a judge in State court related Pati simple application of the principle of justice Rapid Simple Fee in the criminal justice system in State court of Pati, among others ${ }^{19}$ :

- Improving the mental attitude of law enforcement officers

- Provide training or seminars with other agencies to make the perception among law enforcement officials

- Provide strict sanctions against law enforcement officers who do not comply prose associated in dealing with criminal cases

- Provide legal counseling to the public ${ }^{20}$

\subsection{Contributions Principle Of Simple Justice Rapid Simple Fee In The Criminal Justice System For Criminal Justice System Reform In The Future}

The criminal case Fee is expected to be resolved outside the court so as not to make a pile of cases in the courts and for criminal cases weight can be immediately resolved with a quick and precise that the period of four (4) or five (5) times in the trial or one in accordance with the court calendar. So that law enforcement can provide certainty and fairness by applying the theory of law enforcement and progressive theory that justice is real and put a man above the law and uphold the human dignity justice seekers. process for settling disputes out of court through mediation penal (penal

\footnotetext{
${ }^{17}$ Ibid.

${ }^{18}$ Ibid.

${ }^{19} \mathrm{lbid}$.

${ }^{20}$ Ibid.
} 
mediation), restorative justice, diversion in juvenile justice and other forms that thrive in the community. ${ }^{21}$

\section{Closing}

\subsection{Conclusion}

The conclusions which can be drawn in this paper are:

- Application of the principle of judicial quick simple and inexpensive in State court of Pati. Judge attention to values in Act No. 48 of 2009 on justice and Act No. 8 of 1981 on criminal procedural law.

- Obstacles and solutions simple application of the principle of justice Rapid Simple Fee in the criminal justice system in the State court of Pati

Application of the principle of judicial quick simple and inexpensive in the State court of Pati experience barriers to implementation include: Factor Internal, External factors, factors or State Government.

- Contributions principle of simple justice Rapid Simple Fee in the criminal justice system for criminal justice system reform which will come form the inter-agency cooperation integrity of the criminal justice system is better than the police, prosecutors, courts and social institutions. The detention could be reduced in order to quickly complete the settlement immediately, and the process for settling disputes out of court through mediation penal (penal mediation), restorative justice, diversion in juvenile justice and other forms that thrive in the community. It is considered necessary as part of the criminal law reform.

\subsection{Suggestion}

State court Starch is spearheading law enforcement that gives justice to the people as mandated in Act No. 48 of 2009 on the judicial authority that is to examine, hear and decide and apply the principles of Simple Justice, quick and inexpensive should make improvements to institutional performance, seeks to continuously improve the credibility of all components of the judicial institutions in place to serve people seeking justice and the commitment of law enforcement police officers, judges, prosecutors, and advocates in support of realizing the principle of justice is simple, fast and low cost consistent with attending the hearing schedule which has been specified.

\section{References}

\section{Books}

[1] Abu Achmadi and Cholid Narkubo 2005, Metode Penelitian, Jakarta: Bumi Aksara

[2] Andi Hamzah, 2018, Perbandingan Hukum Pidana di Beberapa Negara, Jakarta: Sinar Grafika

\footnotetext{
${ }^{21}$ Interview informant A.A Putu Putra Ariyana, SH (December 9th, 2019, at 09:00 am at the State Court of Pati).
} 
[3] Bagir Manan, 2017, Kekuasaan Kehakiman Indonesia Dalam Undang-Undang Nomor 4 Tahun 2004, Yogyakarta: FH UII

[4] Bernald Tanya L, 2013, Teori Hukum Strategi Tertib Manusia Lintas Ruang dan Generasi, Yogyakarta: Genta Publisihing.

[5] Chairul Huda, 2015, Penerapan Mekanisme Small Claim Court Dalam Sistem Hukum Nasional (Perspektif Hukum Pidana), Jakarta: Badan Pembinaan Hukum Nasional.

[6] Nurhan Bungi, 2003, Analisis Data dan Penelitian Kulaitatif, Pemahamn filosofis dan Metodologis kearah penguasaan Modal Aplikasi, Jakarta: Raja Grafindo Persada.

[7] Marwan Efendy, 2012, Diktat Perkuliahan Sistem Peradilan Pidana, Semarang: Unissula

[8] M. Yahya Harahap, 2017, Pembahasan Permasalahan dan Penerapan KUHAP, Jakarta: Sinar Grafika

[9] Oli Viana Agustine, 2019, Pembahasan Permasalahan dan Penerapan KUHAP, Depok: Raja Grafindo Persada

[10] R. Susilo, 1980, Kitab Undang-Undang Hukum Pidana (KUHAP) serta komentarkomentar pasal demi pasal, Bogor, Jakarta: Politea

[11] Romli Atmasasmita, 2010, Sistem Peradilan Pidana Kontemporer, Jakarta: Kencana

[12] Soerjono Soekanto, 2013, Faktor-Faktor Penegakkan Hukum, Jakarta: PT. Raja Grafindo Persada

[13] Suryono Sutarto, 2005, Hukum Acara pidana, Semarang: Diponegoro University

[14] Satjipto Rahardjo, 2013, Teori Hukum Strategi Tertib Manusia Lintas Ruang dan Generasi, Yogyakarta: Genta Publisihing,

[15] Elucidation of Article 2 (4) of Act No. 48 Of 2009

\section{Constitution}

[1] Act 1945

[2] Act No. 8 of 1981 on Law of Criminal Procedure

[3] Act No. 48 Of 2009 on Judicial Authority

\section{Journals}

[1] Wahyu Widodo, 2014, Journal of Law Creating constructive Koomunikasi InterAgency Law Enforcement, President and Institutions Anti-Corruption Commission in the framework of effective and efficient, FH. Unissula, Semarang 